\section{Pacific Northwest} National Laboratory

Operafed by Battelle for the U.S. Department of Energy

\title{
Demonstration of Strontium Removal from Hanford N-Area Well Water
}

\author{
C. D. Carlson \\ J. R. DesChane \\ T. M. Corneillie
}

September 1998

\section{RECEIVED \\ OCT 131998 \\ OSTI}

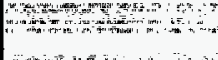

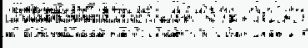

$x=-m$

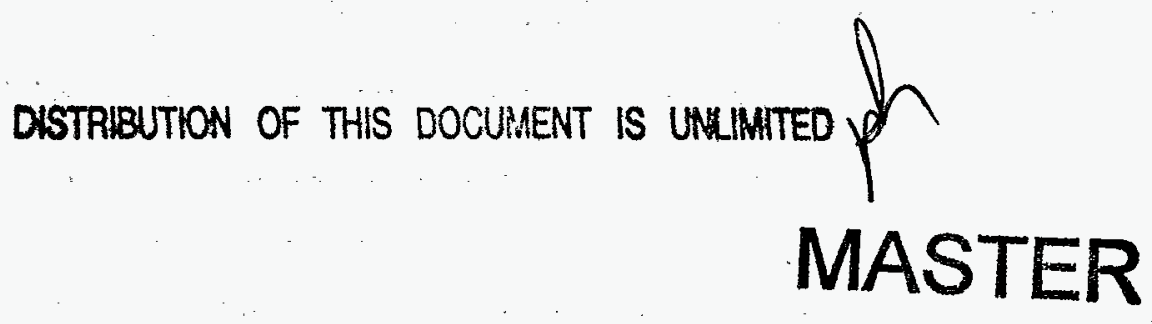

Prepared for the U.S. Department of Energy under Contract DE-AC06-76RLO 1830 


\title{
DISCLAIMER
}

This report was prepared as an account of work sponsored by an agency of the United States Government. Neither the United States Government nor any agency thereof, nor Battelle Memorial Institute, nor any of their employees, makes any warranty, express or implied, or assumes any legal liability or responsibility for the accuracy, completeness, or usefulness of any information, apparatus, product, or process disclosed, or represents that its use would not infringe privately owned rights, Reference herein to any specific commercial product, process, or service by trade name, trademark, manufacturer, or otherwise does not necessarily constitute or imply its endorsement, recommendation, or favoring by the United States Government or any agency thereof, or Battelle Memorial Institute. The views and opinions of authors expressed herein do not necessarily state or reflect those of the United States Government or any agency thereof.

\author{
PACIFIC NORTHWEST NATIONAL LABORATORY \\ operated by \\ BATTELLE \\ for the \\ UNITED STATES DEPARTMENT OF ENERGY \\ under Contract DE-AC06-76RLO 1830
}

Printed in the United States of America

Available to DOE and DOE contractors from the

Office of Scientific and Technical Information, P.O. Box 62, Oak Ridge, TN 37831;

prices available from (615) 576-8401.

Available to the public from the National Technical Information Service, U.S. Department of Commerce, 5285 Port Royal Rd., Springfield, VA 22161

This document was printed on recycled paper.

(9/97) 


\section{DISCLAIMER}

Portions of this document may be illegible electronic image products. Images are produced from the best available original document. 


\section{Demonstration of Strontium Removal from Hanford N-Area Well Water}

C. D. Carlson

J. R. DesChane

T. M. Corneillie

September 1998

Prepared for

the U.S. Department of Energy

under Contract DE-AC06-76RLO 1830

Pacific Northwest National Laboratory

Richland, Washington 99352 



\section{Summary}

As part of the Efficient Separations and Processing Crosscutting Program, the Pacific Northwest National Laboratory ${ }^{(a)}$ conducted this study to demonstrate the efficiency of several ion-exchange materials in removing strontium-90 from actual groundwater from the Hanford N-Springs Pump and Treat Demonstration Facility. The objective of this experiment was to determine the strontium-loading distribution coefficients (Kds) for some titanate ion-exchange materials, modified minerals, and organic ion-exchange resins

The equilibrium uptake data presented in this report are useful for identifying potential materials that are capable of removing strontium from $\mathrm{N}$-Area groundwaters. The data show the relative selectivities of the ion-exchange materials under similar operating conditions, and show that additional flow studies are needed to predict materials capacities and to develop complete ion-exchange process flow sheets.

The materials investigated in this study include commercially available ion exchangers such as IONSIV IE-911 (manufactured by UOP) and SuperLig ${ }^{\circledR} 644^{(\text {b) }}$ (IBC Advanced Technologies, Inc.), and materials produced on an experimental basis by Allied Signal (nonatitanates), Selion Inc. (titanates), and Pennsylvania State University (modified mica). In all, the performance of seven different ion-exchange materials was evaluated using actual $\mathrm{N}$-Area groundwater. The evaluation consisted of the determining strontium batch distribution coefficients, loading, and decontamination factors. Tests were performed at two different solution-to-exchanger mass ratios (i.e., phase ratios) of 2000 and 4000 using actual N-Area groundwater samples from three different wells. Actual N-Area groundwater used in the present study was obtained from three monitoring wells in FY 1998. These samples were taken from wells with strontium- 90 concentrations ranging from 0.25 to $3.9 \mathrm{pCi} / \mathrm{L}$.

The Pennsylvania State University modified mica and the IONSIV IE-911 exhibited the best performance by removing over $95 \%$ of the strontium at both phase ratios. The results of the remaining titanate materials were all within an order of magnitude of the IONSIV IE-911 and the Pennsylvania State University modified mica. Therefore, a cost-benefit comparison is necessary to determine which material would be the best for strontium removal from groundwater.

(a) Pacific Northwest National Laboratory is operated for the U.S. Department of Energy by Battelle under Contract DE-AC06-76RLO 1830.

(b) SuperLig 644 is a registered trademark of IBC Advanced Technolgies, Inc. in Provo, Utah. 



\section{Acknowledgments}

Pacific Northwest National Laboratory (PNNL) collaborates with universities, national laboratories, and industry to develop and test new materials for the pretreatment of nuclear process wastes and groundwaters at Hanford. This work has been performed under the direction of the U. S. Department of Energy's Office of Science and Technology. The experimental work described in this report would not have been possible without the encouragement and resources provided by the Efficient Separations and Processing Crosscutting Program. A special recognition is due to Mr. Lane A. Bray, formerly the Principal Investigator for the Develop and Test Sorbers task at PNNL. In addition, the authors would like to acknowledge the contributions of G. N. Brown and W. F. Bonner of PNNL, and Renee Nielson of $\mathrm{CHI}$ Analytical Field Services, to this effort. 



\section{Contents}

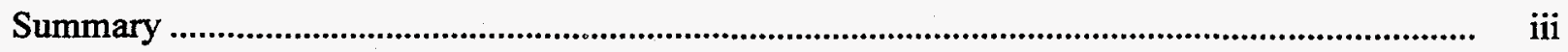

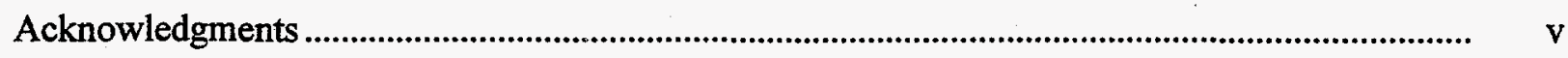

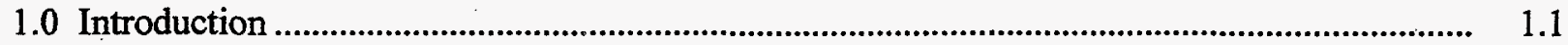

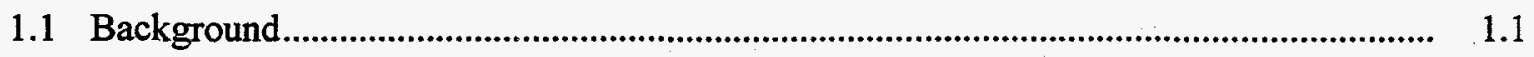

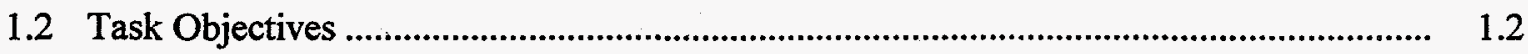

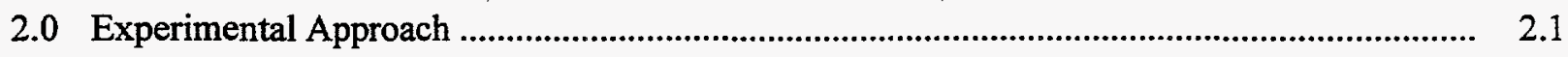

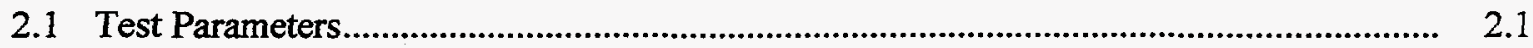

2.2 Ion Exchange Distribution and Decontamination Factor.............................................. 2.3

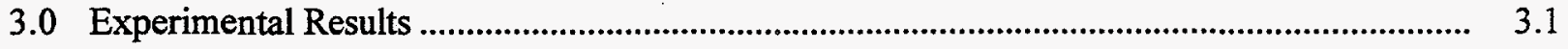

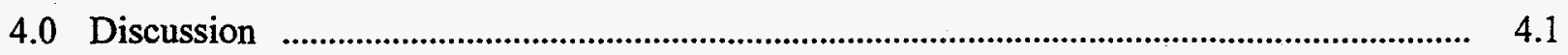

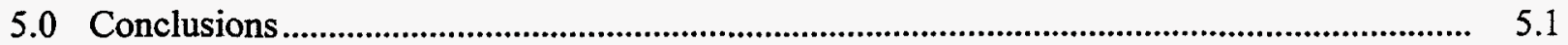

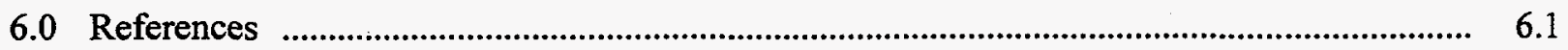

Appendix A - 100-N Area Groundwater Batch Testing Data...................................................... A.1 


\section{Figures}

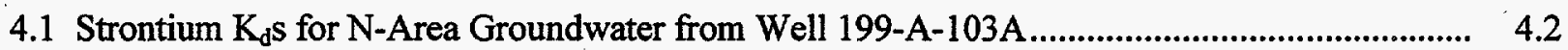

4.2 Strontium $\mathrm{K}_{\mathrm{d}} \mathrm{s}$ for $\mathrm{N}-$ Area Groundwater from Well 199-N-75 .................................................... 4.3

4.3 Strontium $\mathrm{K}_{\mathrm{d}} \mathrm{s}$ for $\mathrm{N}$-Area Groundwater from Well 199-N-106A .............................................4.4

viii 


\section{Tables}

2.1. ICP/MS and Strontium-90 Analysis of N-Area Groundwater Samples ................................. 2.1

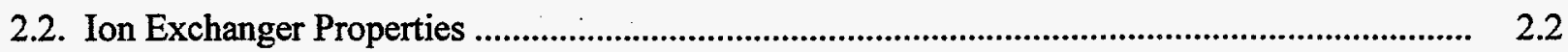

3.1. Strontium Removal Data from Groundwater Sample 199-N-103A …........................................ 3.1

3.2. Strontium Removal Data from Groundwater Sample 199-N-75 ....................................... 3.2

3.3. Strontium Removal Data from Groundwater Sample 199-N-106A .......................................... 3.2 



\subsection{Introduction}

Under the Efficient Separations and Processing Crosscutting Program, the Pacific Northwest National Laboratory (PNNL) ${ }^{(a)}$ conducts experimental ion-exchange studies to evaluate newly emerging materials (Bray, Carson, and Elovich 1990; Bray, Carson, and Elovich 1993; Brown et al. 1995a; Brown et al. 1996a) and technologies for removing cesium, strontium, cobalt, technetium, and transuranic elements from simulated and actual wastes at Hanford. Previous work (Bray et al. 1984; Brown et al. 1995b; Brown, Bray, and Elovich 1995) focused on applications to treat high-level alkaline tank wastes, but many of the technologies can also be applied in process and groundwater remediation (Brown et al. 1996b; Herbst et al. 1995). Ultimately, each process must be evaluated in terms of life-cycle costs, removal efficiency, process chemical consumption and recycle, stability of materials exposed to chemicals and radiation, compatibility with other process streams, secondary waste generation, process and maintenance costs, and final material disposal.

\subsection{Background}

Hanford's 100-N Area N-Springs well water (from wells 199-N-75, 199-N-103A, and 199-N-106A) is known to be contaminated with traces of radioactive strontium-90 and tritium. Other radionuclides and organic and inorganic species have been detected, but generally exist at levels below federal drinking water standards (Dirkes 1990; Hartman and Lindsey 1993). Strontium-90 levels vary between 1000 and $2000 \mathrm{pCi} / \mathrm{L}$, depending upon the water table level. Tritium concentrations are normally about 60,000 $\mathrm{pCi} / \mathrm{L}$. In addition, the groundwater contains high concentrations of nonradioactive strontium $(0.23 \mathrm{ppm})$, calcium (45 ppm), and magnesium (9 ppm), the presence of which frustrates efforts to remediate the strontium-90 using ion-exchange technologies. The major anionic component of the groundwater is carbonate.

The N-Springs Pump and Treat Demonstration Facility currently processes groundwater from the $100-\mathrm{N}$ Area wells at 50 gallons per minute (gpm) using conventional ion-exchange technology. The present system consists of four columns, each capable of holding $65 \mathrm{ft}^{3}$ of a natural zeolite, clinoptilotite. Normally, three columns are connected in series. The fourth column is held offline for disposal and installation of the spent exchanger. The system is typically operated continuously at 50 gpm for 2 weeks, and then the lead column is removed from service. The column previously held in reserve is then placed in service at the end or trailing position, and solution processing is continued. Strontium is removed by the ion exchanger to levels below federal drinking water standards of $0.040 \mathrm{pCi} / \mathrm{L}$. However, the process generates a large amount of solid radioactive waste. Bechtel Hanford, Inc. operators and engineers are searching for methods to improve the process and reduce the amount of secondary waste.

(a) Pacific Northwest National Laboratory is operated for the U.S. Department of Energy by Battelle under Contract DE-AC06-76RLO 1830. 


\subsection{Task Objectives}

The purpose of this task was to assess the performance of several ion exchangers, including a newly identified mica, for removing trace quantities of strontium from actual Hanford N-Springs groundwater. The experimental objective was to determine the relative effectiveness of various ion-exchange materials, including a newly developed modified mica material (PSU modified mica) from the laboratory of Dr. Sridhar Komarneni at Pennsylvania State University (Komarneni, Pidugu, and Amonette 1998), to remove strontium. 


\subsection{Experimental Approach}

The removal of strontium from actual N-Area groundwater was determined using the water from three different wells in two separate tests. The first test was with performed using a liquid-to-solid ratio of 2000 , while the second test was performed on a selected number of ion exchangers using a liquid-tosolid ratio of 4000 . The water used was collected on 7/9/98 between 08:18 and 08:53 from wells 199-N-75, 199-N-103A, and 199-N-106A. The raw data are presented in Appendix A.

\subsection{Test Parameters}

The analyses of the groundwater samples are shown in Table 2.1. The samples were analyzed by inductively coupled plasma/mass spectometry (ICP/MS) and for strontium-90 activity. The results are $\mathrm{ng} / \mathrm{mL}(\mathrm{ppb}$ ) and $\mathrm{pCi} / \mathrm{mL}$ Prior to contacting the solutions with the solids, each of the solutions was spiked with strontium- 85 so that the contacts could be tracked by gamma counting.

Table 2.1. ICP/MS and Strontium-90 Analysis of N-Area Groundwater Samples

\begin{tabular}{|c|c|c|c|}
\hline Analyte & $\begin{array}{l}\text { 199-N-75 } \\
(\mathrm{ng} / \mathrm{mL})\end{array}$ & $\begin{array}{c}\text { 199-N-103A } \\
\text { (ng/mL) }\end{array}$ & $\begin{array}{c}\text { 199-N-106A } \\
\text { (ng/mL) }\end{array}$ \\
\hline$\overline{\mathrm{Li}}$ & $<2$ & $<2$ & 3 \\
\hline$\overline{\mathrm{Be}}$ & $<0.5$ & $<0.5$ & $<0.5$ \\
\hline $\mathrm{Na}$ & 5250 & 5800 & 6350 \\
\hline $\mathrm{Mg}$ & 6250 & 8780 & 6800 \\
\hline $\mathrm{K}$ & 2030 & 2000 & 1960 \\
\hline $\mathrm{Ca}$ & 37,300 & 46,400 & 39,400 \\
\hline $\mathrm{Cr}$ & 1.6 & 3.43 & 2.76 \\
\hline $\mathrm{Mn}$ & $<0.5$ & $<0.5$ & $<0.5$ \\
\hline$\overline{\mathrm{Rb}}$ & 1.58 & 1.40 & 1.28 \\
\hline $\mathrm{Sr}$ & 198 & 234 & 183 \\
\hline Cs & $<0.5$ & 0.7 & $<0.5$ \\
\hline$\overline{\mathrm{Ba}}$ & 30.0 & 38.9 & 23.2 \\
\hline${ }^{90} \mathrm{Sr}^{(\mathrm{a})}$ & $0.556^{(0)}$ & $0.293^{(b)}$ & $3.91^{(b)}$ \\
\hline${ }^{90} \mathrm{Sr} / \mathrm{Sr}$ ratio & $2.03 \times 10^{-8}$ & $9.07 \times 10^{-9}$ & $1.55 \times 10^{-7}$ \\
\hline
\end{tabular}

As stated earlier, the two tests were run using different liquid-to-solid ratios. The reason for using the two different ratios was because the materials were so efficient at removing strontium, the final (i.e., equilibrium) strontium concentrations were very low. To increase the final concentrations, a higher solution ratio test was performed. Because of the limited amount of sample, only those ion-exchange 
materials that showed a high-removal capacity were tested using the higher liquid-to-solid ratio. The PSU modified mica was not available when the low liquid-to-solid ratio test was performed, so it was only tested at the high liquid-to-solid ratio.

Table 2.2 shows the ion-exchange materials that were used for testing. For the 2000 liquid-to-solid ratio test, duplicate 0.0500 -gram samples of each ion exchanger were added to a 125 -mL high-density polyethylene bottle for each of the groundwater samples (see Table 2.1). One hundred milliliters of the strontium-85 spiked groundwater were then added to each bottle, and the bottles were placed in a shaker table for 72 hours. The samples were then filtered through a $0.20-\mu \mathrm{m}$ filter and counted by gamma counting.

Table 2.2. Ion Exchanger Properties

\begin{tabular}{|c|c|c|c|c|c|c|}
\hline $\begin{array}{c}\text { Ion-Exchange } \\
\text { Material }\end{array}$ & $\begin{array}{l}\text { Sample } \\
\text { Identifi- } \\
\text { cation }\end{array}$ & $\begin{array}{c}\text { Liquid/Solid } \\
\text { Ratio }\end{array}$ & Manufacturer & Batch No. & $\rho^{(\mathbf{a})}$ & F-Factor ${ }^{(b)}$ \\
\hline IONSIV IE-911 & A & 2000 & UOP & 99096810002 & 0.85 & 0.9112 \\
\hline R-F Resin & B & 2000 & $\begin{array}{l}\text { Boulder } \\
\text { Scientific }\end{array}$ & $18-210$ & 0.3044 & 0.8190 \\
\hline $\begin{array}{l}\text { Sodium } \\
\text { Nonatitanate }\end{array}$ & $\mathrm{C}$ & 2000 & Allied Signal & $8212-152$ & 0.84 & 0.9393 \\
\hline Sr-Treat & $\mathrm{D}$ & 2000 & Selion, Inc. & H18 & 0.71 & 0.8966 \\
\hline SuperLig® 644 & $\mathrm{E}$ & 2000 & IBC Inc. & 10-SM-171 & 0.22 & 0.9330 \\
\hline TIE-96 & $\mathrm{F}$ & 2000 & UOP & $\begin{array}{c}97579100001 \\
2-A\end{array}$ & 0.77 & 0.8822 \\
\hline IONSIV IE-911 & $\mathrm{G}$ & 4000 & UOP & 99096810002 & 0.85 & 0.9112 \\
\hline Sr-Treat & I & 4000 & Selion, Inc. & $\mathrm{H} 18$ & 0.71 & 0.8966 \\
\hline $\begin{array}{l}\text { PSU Modified } \\
\text { Mica }\end{array}$ & $\mathrm{J}$ & 4000 & $\begin{array}{l}\text { Pennsylvania } \\
\text { State University }\end{array}$ & SK-1 & (b) & 0.9424 \\
\hline
\end{tabular}

For the 4000 liquid-to-solid ratio test, duplicate 0.0500 -gram samples of each ion exchanger were added to a $250-\mathrm{mL}$ high-density polyethylene bottle for each of the groundwater samples (see Table 2.1). Two hundred milliliters of the spike groundwater were then added to each bottle, and the bottles were placed in a shaker table for 72 hours. The samples were then filtered through a $0.20-\mu \mathrm{m}$ filter and counted by gamma counting. 


\subsection{Ion Exchange Distribution and Decontamination Factor}

The batch $\mathrm{K}_{d}\left(\mathrm{~K}_{\mathrm{d}}=[\mathrm{Sr}]_{\text {solid }} /[\mathrm{Sr}]_{\text {liquid }}\right)$ is an equilibrium measure of the overall ability of the solid phase ion-exchange material to remove an ion from solution under the particular experimental conditions that exist during the contact. In most batch $\mathrm{K}_{\mathrm{d}}$ tests, a known quantity of ion-exchange material is placed in contact with a known volume of solution containing the ions of interest (in this case, strontium). The material is allowed to contact the solution for a sufficient time to achieve equilibrium at a constant temperature, after which the solid ion-exchange material and liquid supernate are separated and analyzed. The equation for determining the $\mathrm{K}_{d}$ can be simplified by determining the concentration of the analyte before and after contact, and calculating the quantity of analyte on the ion exchanger by the difference (Equation 2.1)

$$
K_{d}=\frac{\left(C_{i}-C_{f}\right)}{C_{f}} \times \frac{V}{M^{*} F}
$$

where $C_{i}=$ initial amount or activity of the ion of interest in the feed solution prior to contact

$\mathrm{C}_{\mathrm{f}}=$ amount or activity after contact

$\mathrm{V}=$ solution volume

$\mathrm{M}=$ exchanger mass

$F=$ mass of dry ion exchanger divided by the mass of wet ion exchanger ( $F$-factor).

$\mathrm{K}_{\mathrm{d}}(\mathrm{mL} / \mathrm{g})$ represents the theoretical volume of solution that can be processed per mass of exchanger under equilibrium conditions.

Lambda, the theoretical number of bed volumes of solution that can be processed per volume of exchanger, is obtained by multiplying $K_{d}$ by the exchanger bed density, $\rho_{b}(g / m L)$, as shown in Equation 2.2. Lambda is termed the column distribution ratio and is useful for estimating the $0.5 \mathrm{C} / \mathrm{C}_{0}$ point ( $50 \%$ breakthrough) in column-loading experiments.

$$
\lambda=K_{d} \times \rho_{b}
$$

The final method of comparison for ion-exchange materials is the decontamination factor (DF, as shown in Equation 2.3). The DF is the initial activity in solution of the species of interest divided by the final activity in solution of the species of interest.

$$
\mathrm{DF}=\mathrm{C}_{\mathrm{i}} / \mathrm{C}_{\mathrm{f}}
$$




\subsection{Experimental Results}

In this study, only radioactive strontium, rather than total strontium, was measured both before and after contact. This does not effect the $\mathrm{K}_{d}$ or the DF results, but it will affect the calculation of loading of the ion exchangers. Since the actual loading of strontium onto these materials is of interest, the loading of all the strontium was calculated for each experiment. Tables 3.1, 3.2, and 3.3 show the $\mathrm{K}_{d}$, DF, and loading results for the various ion-exchange materials for the groundwater samples (having different strontium -90 content).

Table 3.1. Strontium Removal Data from Groundwater Sample 199-N-103A (Low Strontium-90 Concentration)

\begin{tabular}{|l|c|c|c|c|c|c|}
\hline $\begin{array}{c}\text { Ion-Exchange } \\
\text { Material }\end{array}$ & $\begin{array}{c}\text { Sample } \\
\text { Identifi } \\
\text {-cation }\end{array}$ & $\begin{array}{c}\text { Liquid/Solid } \\
\text { Ratio }\end{array}$ & $\begin{array}{c}\mathbf{K}_{\mathbf{d}} \\
(\mathbf{m L} / \mathbf{g})\end{array}$ & $\begin{array}{c}\text { Total Sr } \\
\text { Loading } \\
(\mathbf{m m o l} / \mathbf{g})\end{array}$ & $\begin{array}{c}90 \text { Sr Loading } \\
(\mathbf{m m o l} / \mathbf{g})\end{array}$ & DF \\
\hline IONSIV IE-911 & A & 2000 & $7.48 \mathrm{E}+04$ & $5.09 \mathrm{E}-03$ & $4.49 \mathrm{E}-11$ & $3.58 \mathrm{E}+01$ \\
\hline R-F Resin & B & 2000 & $1.52 \mathrm{E}+03$ & $2.05 \mathrm{E}-03$ & $1.81 \mathrm{E}-11$ & $1.63 \mathrm{E}+00$ \\
\hline Sodium & C & 2000 & $7.72 \mathrm{E}+03$ & $3.61 \mathrm{E}-03$ & $3.19 \mathrm{E}-11$ & $5.35 \mathrm{E}+00$ \\
\hline Sonatitanate & D & 2000 & $1.57 \mathrm{E}+04$ & $4.55 \mathrm{E}-03$ & $4.01 \mathrm{E}-11$ & $8.27 \mathrm{E}+00$ \\
\hline SuperLig $\circledast 244^{(2)}$ & E & 2000 & $9.27 \mathrm{E}+01$ & $2.22 \mathrm{E}-04$ & $1.96 \mathrm{E}-12$ & $1.04 \mathrm{E}+00$ \\
\hline TIE-96 & F & 2000 & $9.11 \mathrm{E}+03$ & $2.32 \mathrm{E}-03$ & $2.05 \mathrm{E}-11$ & $9.23 \mathrm{E}+00$ \\
\hline IONSIV IE-911 & G & 4000 & $1.24 \mathrm{E}+04$ & $7.70 \mathrm{E}-03$ & $6.80 \mathrm{E}-11$ & $3.90 \mathrm{E}+00$ \\
\hline Sr-Treat & I & 4000 & $7.40 \mathrm{E}+03$ & $6.58 \mathrm{E}-03$ & $5.81 \mathrm{E}-11$ & $2.26 \mathrm{E}+00$ \\
\hline PSU Modified Mica & J & 4000 & $5.07 \mathrm{E}+04$ & $9.62 \mathrm{E}-03$ & $8.50 \mathrm{E}-11$ & $1.33 \mathrm{E}+01$ \\
\hline (a) SuperLig 644 is a registered trademark of IBC Advanced Technologies, Inc., in Provo, Utah. \\
\hline
\end{tabular}


Table 3.2. Strontium Removal Data from Groundwater Sample 199-N-75 (Intermediate Strontium-90 Concentration)

\begin{tabular}{|c|c|c|c|c|c|c|}
\hline $\begin{array}{c}\text { Ion-Exchange } \\
\text { Material }\end{array}$ & $\begin{array}{l}\text { Sample } \\
\text { Identi- } \\
\text { fication }\end{array}$ & $\begin{array}{c}\text { Liquid/Solid } \\
\text { Ratio }\end{array}$ & $\begin{array}{c}K_{d} \\
(m L / g)\end{array}$ & $\begin{array}{c}\text { Total Sr } \\
\text { Loading } \\
\text { (mmol/g) }\end{array}$ & $\begin{array}{c}{ }^{90} \mathrm{Sr} \text { Loading } \\
(\mathrm{mmol} / \mathrm{g})\end{array}$ & DF \\
\hline IONSIV IE-911 & A & 2000 & $9.97 \mathrm{E}+04$ & $4.12 \mathrm{E}-03$ & $8.15 \mathrm{E}-11$ & $4.99 \mathrm{E}+01$ \\
\hline R-F Resin & B & 2000 & $2.91 \mathrm{E}+03$ & $2.45 \mathrm{E}-03$ & $4.85 \mathrm{E}-11$ & $2.19 \mathrm{E}+00$ \\
\hline $\begin{array}{l}\text { Sodium } \\
\text { Nonatitanate }\end{array}$ & $\mathrm{C}$ & 2000 & $1.72 \mathrm{E}+04$ & $3.34 \mathrm{E}-03$ & $6.61 \mathrm{E}-11$ & $1.10 \mathrm{E}+01$ \\
\hline Sr-Treat & $\mathrm{D}$ & 2000 & $2.84 \mathrm{E}+04$ & $4.18 \mathrm{E}-03$ & $8.26 \mathrm{E}-11$ & $1.38 \mathrm{E}+01$ \\
\hline SuperLig® 644 & $\mathrm{E}$ & 2000 & $1.03 \mathrm{E}+02$ & $2.08 \mathrm{E}-04$ & $4.11 \mathrm{E}-12$ & $1.04 \mathrm{E}+00$ \\
\hline TIE-96 & $F$ & 2000 & $1.41 \mathrm{E}+04$ & $2.05 \mathrm{E}-03$ & $4.05 \mathrm{E}-11$ & $1.37 \mathrm{E}+01$ \\
\hline IONSIV IE-911 & $\mathrm{G}$ & 4000 & $2.14 \mathrm{E}+04$ & $7.29 \mathrm{E}-03$ & $1.44 \mathrm{E}-10$ & $6.11 \mathrm{E}+00$ \\
\hline Sr-Treat & I & 4000 & $1.42 \mathrm{E}+04$ & $6.39 \mathrm{E}-03$ & $1.26 \mathrm{E}-10$ & $4.52 \mathrm{E}+00$ \\
\hline PSU Modified Mica & $\mathbf{J}$ & 4000 & $7.41 E+04$ & $8.61 \mathrm{E}-03$ & $1.70 \mathrm{E}-10$ & $1.83 \mathrm{E}+01$ \\
\hline
\end{tabular}

Table 3.3. Strontium Removal Data from Groundwater Sample 199-N-106A (High Strontium-90 Concentration)

\begin{tabular}{|l|c|c|c|c|c|c|}
\hline \multicolumn{1}{|c|}{$\begin{array}{c}\text { Ion-Exchange } \\
\text { Material }\end{array}$} & $\begin{array}{c}\text { Sample } \\
\text { Identifi- } \\
\text { cation }\end{array}$ & $\begin{array}{c}\text { Liquid/Solid } \\
\text { Ratio }\end{array}$ & $\begin{array}{c}\mathbf{K}_{\mathbf{d}} \\
(\mathbf{m L} / \mathbf{g})\end{array}$ & $\begin{array}{c}\text { Total Sr } \\
\text { Loading } \\
(\mathbf{m m o l} / \mathbf{g})\end{array}$ & $\begin{array}{c}90 \\
\text { Sr Loading } \\
(\mathbf{m m o l} / \mathbf{g})\end{array}$ & DF \\
\hline IONSIV IE-911 & A & 2000 & $9.01 \mathrm{E}+04$ & $4.01 \mathrm{E}-03$ & $6.05 \mathrm{E}-10$ & $4.28 \mathrm{E}+01$ \\
\hline $\begin{array}{l}\text { R-F Resin } \\
\text { Nonatium }\end{array}$ & B & 2000 & $2.60 \mathrm{E}+03$ & $2.11 \mathrm{E}-03$ & $3.20 \mathrm{E}-10$ & $2.08 \mathrm{E}+00$ \\
\hline Sr-Treat & D & 2000 & $1.40 \mathrm{E}+04$ & $3.06 \mathrm{E}-03$ & $4.62 \mathrm{E}-10$ & $8.96 \mathrm{E}+00$ \\
\hline SuperLig® 644 & E & 2000 & $8.95 \mathrm{E}+01$ & $1.23 \mathrm{E}-04$ & $1.85 \mathrm{E}-11$ & $1.04 \mathrm{E}+00$ \\
\hline TIE-96 & F & 2000 & $1.23 \mathrm{E}+04$ & $1.95 \mathrm{E}-03$ & $2.95 \mathrm{E}-10$ & $1.16 \mathrm{E}+01$ \\
\hline IONSIV IE-911 & G & 4000 & $1.62 \mathrm{E}+04$ & $6.56 \mathrm{E}-03$ & $9.91 \mathrm{E}-10$ & $4.68 \mathrm{E}+00$ \\
\hline Sr-Treat & I & 4000 & $1.13 \mathrm{E}+04$ & $5.83 \mathrm{E}-03$ & $8.80 \mathrm{E}-10$ & $3.63 \mathrm{E}+00$ \\
\hline PSU Modified Mica & J & 4000 & $7.32 \mathrm{E}+04$ & $7.62 \mathrm{E}-03$ & $1.15 \mathrm{E}-09$ & $1.89 \mathrm{E}+01$ \\
\hline
\end{tabular}




\subsection{Discussion}

The strontium batch $\mathrm{K}_{d} \mathrm{~s}$ for this testing are shown in Figures $4.1,4.2$, and 4.3. Since the final (i.e., equilibrium) strontium concentration for each of these tests is well below the values for the groundwater, these results are mainly useful in determining the relative effectiveness of each of the ion exchangers.

Figure 4.1 shows the results for the $199-\mathrm{N}-103 \mathrm{~A}$ well water. This sample had the lowest strontium-90 concentration but the highest total strontium concentration. For the test with the lower liquid-to-solid ratio (the first six columns), the crystalline silico-titanate (IONSIV IE-911) had the best strontium removal, but the PSU modified mica material was not available for that test. The last three columns represent the higher liquid-to-solid ratio test. In this test, the PSU modified mica gave the best removal.

For the low liquid-to-solid test, the IONSIV IE-911 removed approximately $97 \%$ of the strontium from the groundwater. In the higher liquid-to-solid test, the IONSIV IE-911 removed about $75 \%$ of the strontium while the PSU modified mica removed $93 \%$ of the strontium. Figures 4.2 (results from 199-N-75 well water) and 4.3 (results from 199-N-106A well water) show the same trends in the relative efficiency of strontium removal. 


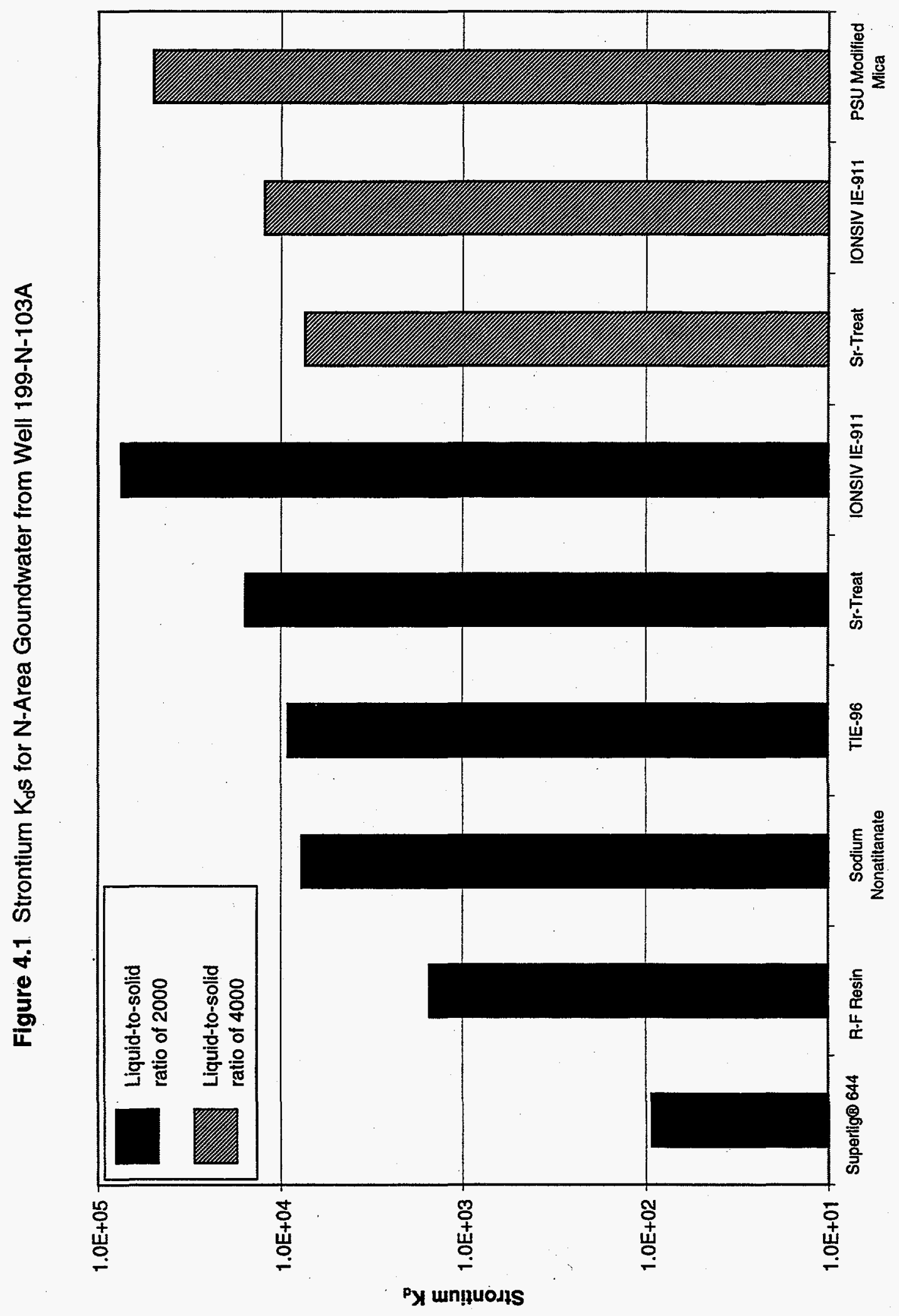


Figure 4.2. Strontium $K_{d} S$ for N-Area Groundwater from Well 199-N-75

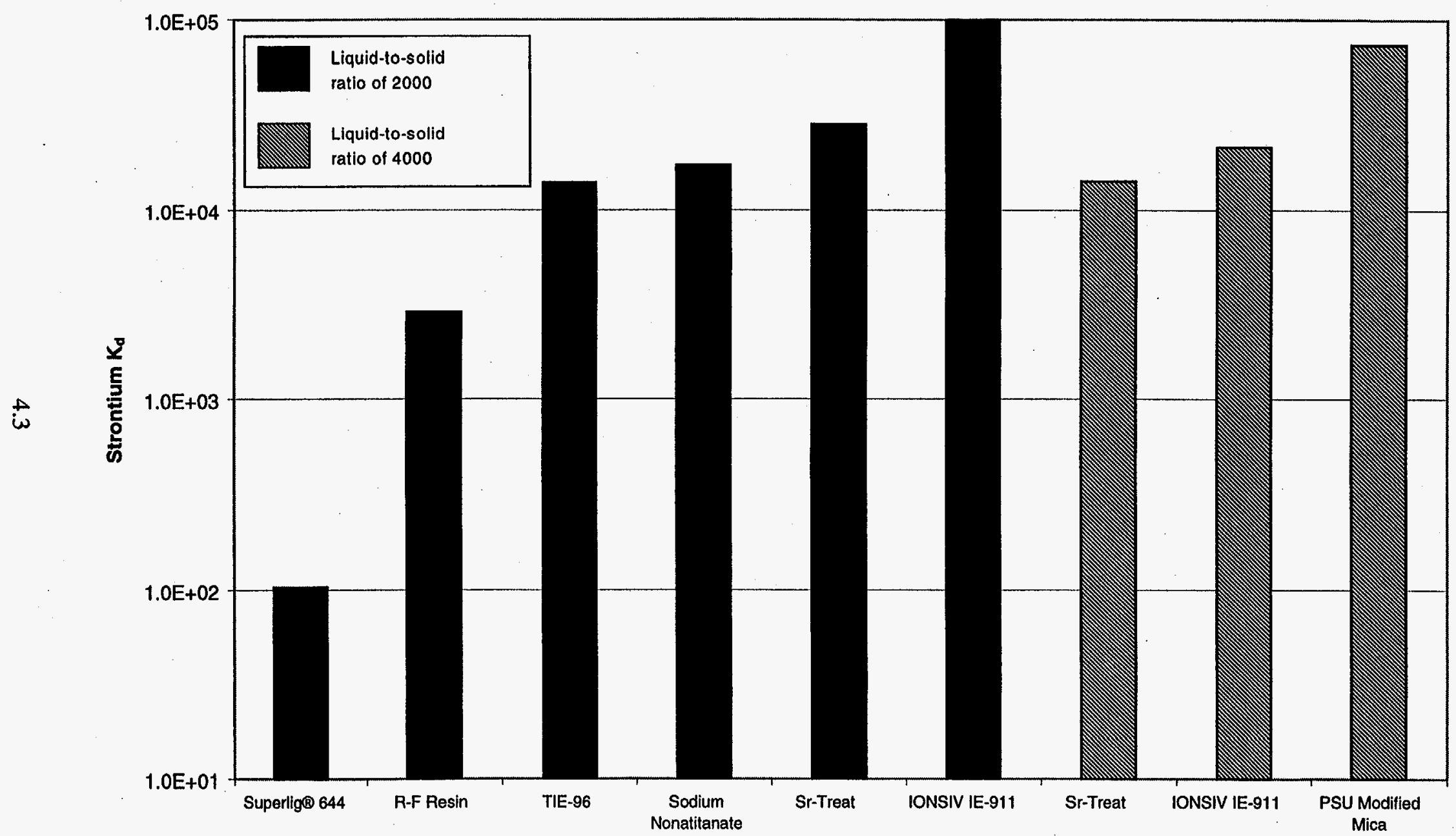




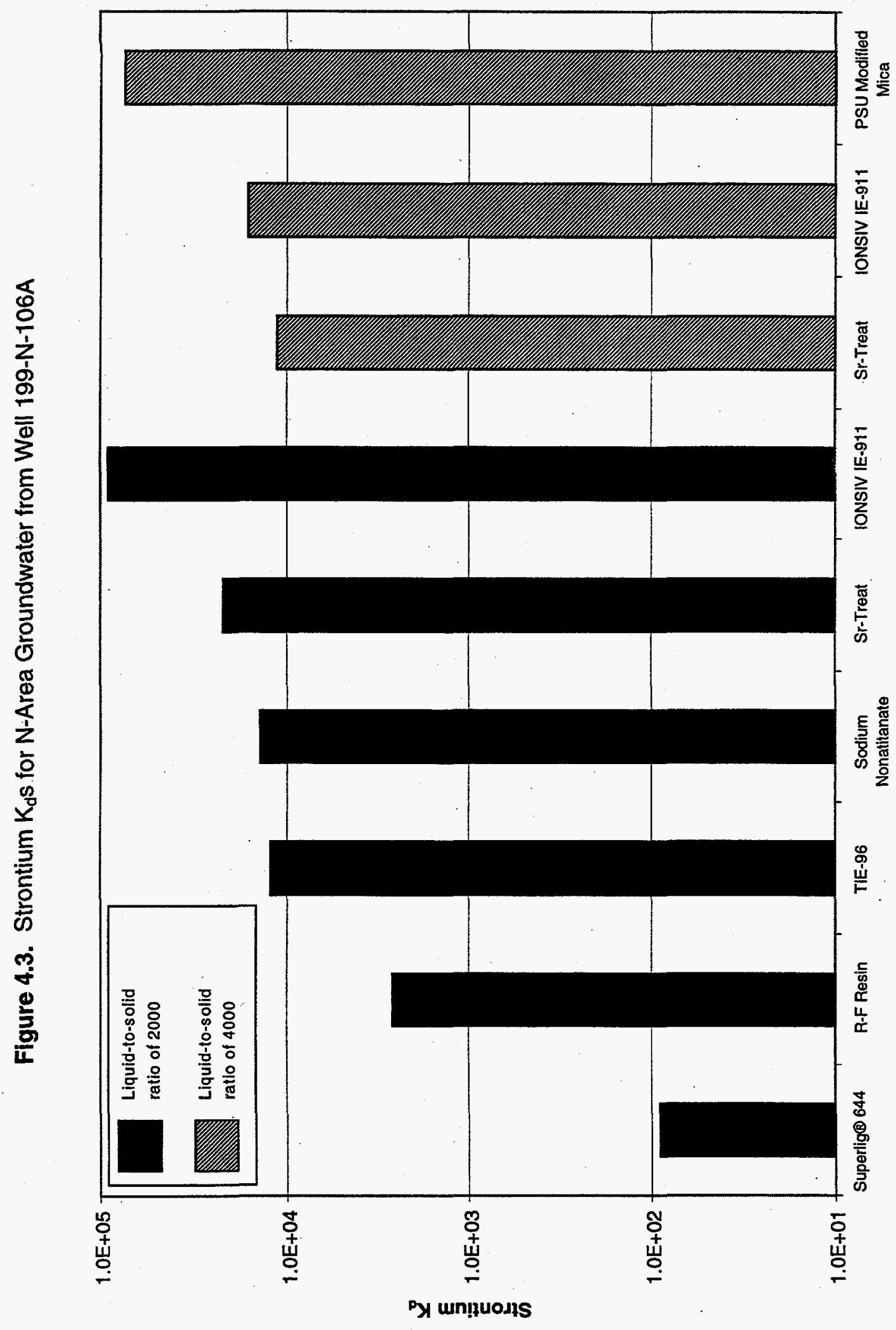




\subsection{Conclusions}

This report evaluates the strontium removal efficiency for seven different ion-exchange materials including inorganic titanate materials (IONSIV IE-911, sodium nonatitanate, and Sr-Treat); modified minerals (TIE-96 and PSU modified mica); and regenerable organic resins (R-F Resin and SuperLigß 644). All of the materials tested here are commercially available except for the PSU modified mica provided by Dr. Komarneni at Pennsylvania State University. Because of the low concentrations of strontium in the groundwater samples and the extent of removal of strontium, these results should only be used to relate the relative efficiency of these materials for the removal of strontium from N-Area groundwater.

For the removal of strontium, the PSU modified mica showed the best strontium removal. The crystalline silico-titanate (IONSIV IE-911) was the second best in strontium removal. The PSU modified mica had approximately five times the efficiency of removing strontium from this groundwater as the IONSIV IE-911. The remaining materials had one third or less of the removal efficiency of IONSIV IE-911. The titanate materials (including the TIE-96) all have similar removal capacities while the organic resins are one to two orders of magnitude less efficient than the inorganic materials.

While the PSU modified mica is the best at removing strontium, the physical form of the material is different. All of the commercially available materials are in a form that can be used in an ion-exchange column. The PSU modified mica is an experimental material in powdered form. The powdered form gives the material a higher surface area, and it does not have a binder to take up part of the volume. Although the binder would reduce the effective capacity of the PSU modified mica by as much as $40 \%$ to $60 \%$, it would still have a higher strontium removal capacity. Another advantage of the PSU modified mica is that it is made from a cheap, readily available mineral. The high removal capacity of the PSU modified mica would makes it a candidate for additional studies for the removal of strontium from groundwater. The economics of making this material into an engineered form suitable for use in ion-exchange columns should be determined so that its cost may be compared to the other ion-exchange materials.

When considering all of the materials, the ability to regenerate the organic resins must be taken into consideration. In high-level waste applications, the stability of the materials can be an important factor, but the radiation field in the removal of strontium from $\mathrm{N}$-Area groundwater is relatively low, and ion-exchange material stability will not be a factor. Because of the relatively low radiation field, the regenerable resins are good candidates. If the number of cycles that these resins can be used is relatively high, then the overall cost of using them may be low enough to make them a reasonable alternative. Before an informed judgement can be made of the relative cost of the regenerable resins compared to the one-pass inorganic materials, additional tests must be performed to determine the lifetime of the resins. 


\subsection{References}

Bray, L. A., L. K. Holton, T. R. Meyers, G. M. Richardson, and B. M. Wise. 1984. Experimental Data Developed to Support the Selection of a Treatment Process for West Valley Alkaline Supernatant. PNL-4969, Pacific Northwest Laboratory, Richland, Washington.

Bray, L. A., K. J. Carson, and R. J. Elovich. 1990. Cesium Recovery Using Savannah River Laboratory Resorcinol-Formaldehyde Ion Exchange Resin. PNL-7273, Pacific Northwest Laboratory, Richland, Washington.

Bray, L. A., K. J. Carson, and R. J. Elovich. 1993. Initial Evaluation of Sandia National Laboratory Prepared Crystalline Silico-Titanates for the Recovery of Cesium. PNL-8847, Pacific Northwest Laboratory, Richland, Washington.

Brown, G. N., S. R. Adami, L. A. Bray, S. A. Bryan, C. D. Carlson, K. J. Carson, J. R. DesChane, R. J. Elovich, S. J. Forbes, J. A. Franz, J. C. Linehan, W. J. Shaw, P. K. Tanaka, and M. R. Telander. 1995a. Chemical and Radiation Stability of SuperLig ${ }^{\circledR}$ 644, Resorcinol-Formaldehyde, and CS-100 Cesium Ion Exchange Materials. PNL-10772, Pacific Northwest National Laboratory, Richland, Washington.

Brown, G. N., J. R. Bontha, C. D. Carlson, K. J. Carson, J. R. DesChane, R. J. Elovich, D. E. Kurath, P. K. Tanaka, D. W. Edmonson, D. L. Herting, and J. R. Smith. 1995b. Ion Exchange Removal of Cesium from Simulated and Actual Supernate from Hanford Tanks 241-SY-101 and 241-SY-103. PNL-10792, Pacific Northwest National Laboratory, Richland, Washington.

Brown, G. N., L. A. Bray, and R. J. Elovich. 1995. Evaluation and Comparison of SuperLig® 644, Resorcinol-Formaldehyde and CS-100 Ion Exchange Materials for the Removal of Cesium from Simulated Alkaline Supernate. PNL-10486, Pacific Northwest National Laboratory, Richland, Washington.

Brown, G. N., L. A. Bray, C. D. Carlson, K. J. Carson, J. R. DesChane, R. J. Elovich, F. V. Hoopes, D. E. Kurath, L. L. Nenninger, and P. K. Tanaka. 1996a. Comparison of Organic and Inorganic Ion Exchangers for Removal of Cesium and Strontium from Simulated and Actual Hanford 241-AW-101 DSSF Tank Waste. PNL-10920, Pacific Northwest National Laboratory, Richland, Washington.

Brown, G. N., K. J. Carson, J. R. DesChane, R. J. Elovich, T.M. Kafka, and L. R. White. 1996b. Ion Exchange Removal of Strontium from Simulated and Actual $N$-Springs Well Water at the Hanford 100-N Area. PNL-11198, Pacific Northwest National Laboratory, Richland, Washington.

Dirkes, R. L. 1990. 1988 Hanford Riverbank Springs Characterization Report. PNL-7500, Pacific Northwest Laboratory, Richland, Washington. 
Hartman, M. J., and K. A. Lindsey. 1993. Hydrogeology of the 100-N Area, Hanford Site, Washington. WHC-SD-EN-EV-027, Westinghouse Hanford Company, Richland, Washington.

Herbst, R. S., K. N. Brewer, T. A. Todd, T. M. Kafka, L. R. White, and L. A. Bray. 1995.

Decontamination of TAN Injection Well Water Using 3MWeb Technology. INEL-95/0589, Lockheed Idaho Technologies Company, Idaho Falls, Idaho.

Komarneni, S., R. Pidugu, and J. E. Amonette. 1998. "Synthesis of Na-4 - Mica from Metakaolinite and MgO: Characterization \& $\mathrm{Sr}^{2+}$ Uptake Kinetics." Journal of Materials Chemistry 8(205-208). 
Appendix A

100-N Area Groundwater Batch Testing Data 


\section{Appendix A}

\section{0-N Area Groundwater Batch Testing Data}

The raw data for the groundwater batch testing of $100-\mathrm{N}$-Area groundwater samples are included in

Tables A.1 and A.2. Table A.1 contains the data from the 2000 liquid-to-solid ratio test, and Table A.2 contains the data from the 4000 liquid-to-solid ratio test. 
Table A.1. Data From Groundwater Batch Test, 2000 Liquid-to-Solid Ratio

\begin{tabular}{|c|c|c|c|c|c|c|c|c|c|c|c|c|c|c|c|}
\hline Sample & IX Resin & Activity & $\begin{array}{l}\text { Mass of } \\
\text { Solution }\end{array}$ & $\begin{array}{l}\text { Volume of } \\
\text { Solution }\end{array}$ & $\begin{array}{c}\text { Mass of } \\
\text { Exchanger }\end{array}$ & F-factor & $\mathbf{K}_{d}$ & Lamda & DF & $\mathrm{SrC}_{i}$ & $\mathrm{SrC}_{\mathrm{r}}$ & \% Removed & Loading & ${ }^{90} \mathrm{Sr}$ Loading & Final Sr Conc. \\
\hline N-75-A1 & $\mathrm{E}-911$ & 7286 & 93.3 & 93.55259 & 0.05255 & 0.91122 & 99236.67 & 84351.17 & 51.79399 & 198 & 3.822837 & 98.06927 & 0.003945 & $7.8 \mathrm{E}-11$ & $4.36 \mathrm{E}-11$ \\
\hline $\mathrm{N}-75-\mathrm{A} 2$ & IE-911 & 7874 & 99.7 & 99.96992 & 0.05136 & 0.91122 & 100239 & 85203.12 & 47.92621 & 198 & 4.131351 & 97.91346 & 0.004307 & $8.51 \mathrm{E}-11$ & $4.72 \mathrm{E}-11$ \\
\hline N-103A-A1 & IE-91I & 5231 & 99.5 & 99.76938 & 0.05093 & 0.91122 & 72415.48 & 61553.15 & 34.68457 & 234 & 6.746515 & 97.11687 & 0.005081 & $4.49 \mathrm{E}-11$ & $7.7 \mathrm{E}-11$ \\
\hline $\mathrm{N}-103 \mathrm{~A}-\mathrm{A} 2$ & $|\mathrm{E}-9| 1$ & 4918 & 99.8 & 100.0702 & 0.05106 & 0.91122 & 77196.69 & 65617.19 & 36.89203 & 234 & 6.342834 & 97.28939 & 0.005092 & $4.5 \mathrm{E}-11$ & $7.24 \mathrm{E}-11$ \\
\hline$\overline{\mathrm{N}-106 \mathrm{~A}-\mathrm{AI}}$ & IE-911 & 4028 & 98.8 & 99.06748 & 0.0507 & 0.91122 & 95536.84 & 81206.31 & 45.55238 & 183 & 4.062744 & 97.77992 & 0.00399 & $6.02 \mathrm{E}-10$ & $4.64 \mathrm{E}-11$ \\
\hline N-106A-A2 & IE-911 & 4586 & 99.9 & 100.1705 & 0,05062 & 0.91122 & 84716.53 & 72009.05 & 40.00981 & 183 & 4.625557 & 97.47237 & 0.004029 & $6.08 \mathrm{E}-10$ & $5.28 \mathrm{E}-11$ \\
\hline$\overline{\mathrm{N}-75-\mathrm{B} 1}$ & RF-BSC-210 & 168174 & 100.3 & 100.5715 & 0.05163 & 0.81905 & 2958.416 & 900.5417 & 2.243932 & 198 & 88.23797 & 55.43537 & 0.00244 & $4.82 \mathrm{E}-11$ & 1.01E-09 \\
\hline$\overline{N-75-B 2}$ & $\mathrm{RF}-\mathrm{BSC}-210$ & 775948 & 99.2 & 99.46857 & 0.04867 & 0.81905 & 2856.53 & 869.5278 & 2.144787 & 198 & 92.31686 & 53.37533 & 0.002465 & $4.87 \mathrm{E}-11$ & $1.05 \mathrm{E}-09$ \\
\hline N-103A-B1 & RF-BSC-210 & 109676 & 99.6 & 99.86965 & 0.05 & 0.81905 & 1595.577 & 485.6938 & 1.654282 & 234 & 141.4511 & 39.5508 & 0.00211 & $1.86 \mathrm{E}-11$ & $1.61 \mathrm{E}-09$ \\
\hline N-103A-B2 & RF-BSC-210 & 113352 & 101.3 & 101.5743 & 0.05117 & 0.81905 & 1455.685 & 443.1104 & 1.600633 & 234 & 146.1921 & 37.52473 & 0.001989 & $1.76 \mathrm{E}-11$ & 1.67E-09 \\
\hline N-106A-B1 & RF-BSC-210 & 90369 & 100 & T00.2707 & 0.04963 & 0.81905 & 2541.7 & 773.6935 & 2.030398 & 183 & 91.14849 & 50.19208 & 0.002118 & $3.2 \mathrm{E}-10$ & 1.04E-09 \\
\hline N-106A-B2 & RF-BSC-210 & 86301 & 100.2 & 100.4713 & 0.05195 & 0.81905 & 2659.04 & 809.4118 & 2.126105 & 183 & 87.0454 & 52.43421 & 0.002118 & $3.2 \mathrm{E}-10$ & $9.93 \mathrm{E}-10$ \\
\hline $\bar{N}-75-\mathrm{Cl}$ & AS NaTi & 32601 & 100.3 & 100.5715 & 0.06239 & 0.93933 & 18148.49 & 15244.73 & 11.57544 & 198 & 17.10518 & 91.36102 & 0.003328 & $6.58 \mathrm{E}-11$ & $1.95 \mathrm{E}-10$ \\
\hline$\overline{N-75-C 2}$ & AS NaTi & 36530 & 98.8 & 99.06748 & 0.06023 & 0.93933 & 16338.13 & 13724.03 & 10.33044 & 198 & 19.16666 & 90.31987 & 0.003357 & $6.63 \mathrm{E}-11$ & $2.19 \mathrm{E}-10$ \\
\hline $\mathrm{N}-103 \mathrm{~A}-\mathrm{Cl}$ & AS NaTi & 36074 & 100.8 & 101.0729 & 0.05924 & 0.93933 & 7319.056 & 6148.007 & 5.029523 & 234 & 46.52529 & 80.1174 & 0.003651 & $3.22 \mathrm{E}-11$ & $5.31 \mathrm{E}-10$ \\
\hline $\mathrm{N}-103 \mathrm{~A}-\mathrm{C} 2$ & AS NaTi & 31899 & 99.6 & 99.86965 & 0.06142 & 0.93933 & 8114.732 & 6816.375 & 5.687796 & 234 & 41.14072 & 82.4185 & 0.003579 & $3.16 \mathrm{E}-11$ & $4.7 \mathrm{E}-10$ \\
\hline N-106A-Cl & AS NaTi & 18557 & 99 & 99.26802 & 0.06141 & 0.93933 & 15294.62 & 12847.48 & 9.887643 & $\overline{183}$ & 18.71707 & 89.77209 & 0.003031 & $4.57 \mathrm{E}-10$ & $2.14 \mathrm{E}-10$ \\
\hline $\mathrm{N}-106 \mathrm{~A}-\mathrm{C2}$ & AS NaTí & 22834 & 99 & 99.26802 & 0.05867 & 0.93933 & 12672.92 & 10645.25 & 8,035605 & 183 & 23.03096 & 87.41478 & 0.003089 & $4.66 \mathrm{E}-10$ & $2.63 \mathrm{E}-10$ \\
\hline
\end{tabular}


Table A.1. (contd)

\begin{tabular}{|c|c|c|c|c|c|c|c|c|c|c|c|c|c|c|c|}
\hline Sample & IX Resin & Activity & $\begin{array}{l}\text { Mass of } \\
\text { Solution }\end{array}$ & $\begin{array}{l}\text { Volume of } \\
\text { Solution }\end{array}$ & $\begin{array}{c}\text { Mass of } \\
\text { Exchanger }\end{array}$ & F-factor & $\mathbf{K}_{\mathbf{d}}$ & Lamda & DF & $\mathrm{SrC}_{\mathbf{l}}$ & $\operatorname{SrC}_{t}$ & \% Removed & Loading & ${ }^{90} \mathrm{Sr}$ Loading & $\begin{array}{l}\text { Final Sr } \\
\text { Conc. }\end{array}$ \\
\hline $\mathrm{N}-75-\mathrm{DI}$ & \begin{tabular}{|l|l|} 
Sr Treat \\
\end{tabular} & 28099 & & & 0.04976 & 0.89664 & 27879.13 & 19794.18 & 13.43005 & 198 & 14.74306 & 92.55401 & 0.004206 & $8.31 \mathrm{E}-11$ & $1.68 \mathrm{E}-10$ \\
\hline N-75-D2 & Sr Treat & 26790 & 100.1 & 100.371 & 0.0507 & 0.89664 & 28893.35 & 20514.28 & 14.08626 & 198 & 14.05625 & 92.90089 & 0.004156 & $8.21 \mathrm{E}-11$ & $1.6 \mathrm{E}-10$ \\
\hline N-103A-DI & Sr Treat & 21022 & 98.9 & 99.16775 & 0.05201 & 0.89664 & 16226.73 & 11520.98 & 8.63072 & 234 & 27.11245 & 88.41348 & 0.004502 & $3.98 \mathrm{E}-11$ & $3.09 \mathrm{E}-10$ \\
\hline N-103A-D2 & Sr Treat & 22956 & 99.3 & 99.56884 & 0.05059 & 0.89664 & 15153.61 & 10759.06 & 7.903598 & 234 & 29.60677 & 87.34753 & 0.004391 & $4.05 \mathrm{E}-11$ & $3.38 \mathrm{E}-10$ \\
\hline N-106A-D1 & Si Treat & 16000 & 100.5 & 100.7721 & 0.04919 & 0.89664 & 23916.7 & 16980.86 & 11.46781 & 183 & 16.13801 & 91.18141 & 0.003901 & $5.89 \mathrm{E}-10$ & $1.84 \mathrm{E}-10$ \\
\hline $\mathrm{N}-106 \mathrm{~A}-\mathrm{D} 2$ & Sr Treat & 19024 & 100.1 & 100.371 & 0.04762 & 0.89664 & 20321.78 & 14428.47 & 9.644922 & 183 & 19.18809 & 89.5147 & 0.003941 & $5.95 \mathrm{E}-10$ & $2.19 \mathrm{E}-10$ \\
\hline N-75-E1 & Superlig 644 & 362446 & 99.6 & 99.86965 & 0.04927 & 0.93295 & 89.46715 & 19.68277 & 1.041179 & 198 & 190.1691 & 3.954994 & 0.000181 & $3.58 \mathrm{E}-12$ & $2.17 \mathrm{E}-09$ \\
\hline N-75-E2 & Superlig 644 & 358249 & 100.2 & 100.4713 & 0.04895 & 0.93295 & 117.43 & 25.83461 & 1.053376 & 198 & 187.967 & 5.067162 & 0.000235 & $4.64 \mathrm{E}-12$ & $2.15 \mathrm{E}-09$ \\
\hline N-103A-El & Superlig 644 & 174719 & 100.9 & T01.1732 & 0.04849 & 0.93295 & 85.96573 & 18.91246 & 1.038439 & 234 & 225.3383 & 3.701601 & 0.000206 & $1.82 \mathrm{E}-12$ & $2.37 \mathrm{E}-09$ \\
\hline N-103A-E2 & Superlig 644 & 173535 & 99.8 & 100.0702 & 0.04915 & 0.93295 & 99.34885 & 21.85675 & 1.045524 & 234 & 223.8112 & 4.354176 & 0.000237 & $2.09 \mathrm{E}-12$ & $2.55 \mathrm{E}-09$ \\
\hline N-106A-E1 & Superlig 644 & 176408 & 99.1 & 99.36829 & 0.05206 & 0.93295 & 82.07601 & 18,05672 & 1.040117 & 183 & 177.9296 & 2.770689 & 0.00011 & $1.67 \mathrm{E}-11$ & $2.03 \mathrm{E}-09$ \\
\hline N-106A-E2 & Superlig 644 & 175628 & 100.4 & 100.6718 & 0.04981 & 0.93295 & 96.91611 & 21.32154 & 1.044737 & $\overline{183}$ & 177.1429 & 3.200595 & 0.000135 & $2.04 \mathrm{E}-11$ & $2.02 \mathrm{E}-09$ \\
\hline N-75-F & \begin{tabular}{|l|} 
TIE-96 \\
\end{tabular} & 27356 & 98.6 & 98.86694 & 0.10173 & 0.88218 & 14095.45 & 10814.03 & 13.79482 & 198 & 14.35322 & 92.7509 & 0.002037 & $4.03 \mathrm{E}-11$ & $1.64 \mathrm{E}-10$ \\
\hline N-75-F2 & TIE-96 & 27756 & 99.5 & 99.76938 & 0.10144 & 0.88218 & 14043.13 & 10773.89 & 13.59602 & 798 & 14.56309 & 92.6449 & 0.002059 & $4.07 \mathrm{E}-11$ & $1.66 \mathrm{E}-10$ \\
\hline N-103A-FI & TIE-96 & 19747 & 99 & 99.26802 & 0.10012 & 0.88218 & 9202.546 & 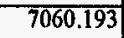 & 9.187978 & 234 & 25.46806 & 89.11621 & 0.00236 & $2.08 \mathrm{E}-11$ & $2.91 \mathrm{E}-10$ \\
\hline N-103A-F2 & TIE-96 & 19563 & 99.1 & 99.36829 & 0.10335 & 0.88218 & 9018.129 & \begin{tabular}{|c|}
6918.708 \\
\end{tabular} & 9.274396 & 234 & 25.23075 & 89.21763 & 0.002291 & $2.02 \mathrm{E}-11$ & $2.88 \mathrm{E}-10$ \\
\hline N-106A-F1 & TIE-96 & 16138 & 100 & 100.2707 & 0.09667 & 0.88218 & 12192.52 & 9354.101 & 11.36975 & 183 & 16.2772 & 91.10535 & 0.001974 & $2.98 \mathrm{E}-10$ & $1.86 \mathrm{E}-10$ \\
\hline N-106A-F2 & TIE-96 & 15497 & 100.1 & 100.371 & 0.09921 & 0.88218 & 12431.58 & 9537.506 & 11.84003 & 183 & 15.63067 & 91.45865 & 0.001933 & $2.92 \mathrm{E}-10$ & $1.78 \mathrm{E}-10$ \\
\hline & & & & & & & & & & & & & & & \\
\hline$N-75-X^{(j)}$ & & 377371 & & & & & & & & & & & & & \\
\hline$N-103 A \cdot X^{(1)}$ & & 181435 & & & & & & & & & & & & & \\
\hline $\mathrm{N}-106 \mathrm{~A}-\mathrm{X}^{(\mathrm{da})}$ & & 183485 & & & & & & & & & & & & & \\
\hline
\end{tabular}


Table A.2. Data From Groundwater Batch Test, 4000 Liquid-to-Solid Ratio

\begin{tabular}{|c|c|c|c|c|c|c|c|c|c|c|c|c|c|c|c|}
\hline Sample & IX Resin & Activity & $\begin{array}{l}\text { Mass of } \\
\text { Solution }\end{array}$ & $\begin{array}{l}\text { Volume of } \\
\text { Solution }\end{array}$ & $\begin{array}{c}\text { Mass of } \\
\text { Exchanger }\end{array}$ & F-factor & $\mathbf{K}_{\mathbf{d}}$ & Lamda & DF & $\operatorname{Sr} C_{i}$ & $\mathrm{SrC}_{\mathbf{r}}$ & $\%$ Removed & Loading & ${ }^{90} \mathrm{Sr}$ Loading & Final Sr Conc. \\
\hline N-75-G & IIE-911 & 19659 & \begin{tabular}{|l|}
196.3 \\
\end{tabular} & 196.8314 & 0.056 & 0.91122 & 23884.78 & 20302.06 & 7.1921 & 198 & $3 \longdiv { 2 7 . 5 3 0 2 1 }$ & 86.09586 & 0.006838 & $1.35 \mathrm{E}-10$ & $3.14 \mathrm{E}-10$ \\
\hline $\mathrm{N}-75-\mathrm{G} 2$ & IE-911 & 28085 & 197.9 & 198.4358 & 0.0464 & 0.91122 & \begin{tabular}{|l|l}
18934.4 \\
\end{tabular} & 16094.24 & 5.034342 & 198 & \begin{tabular}{l|l}
39.32987 \\
\end{tabular} & 80.13643 & 0.00774 & T.53E-10 & $4.49 \mathrm{E}-10$ \\
\hline N-103A-G1 & $\bar{E}-911$ & 38581 & 196.4 & 196.9317 & 0.0493 & 0.91122 & 11715.65 & 9958.305 & 3.67252 & 234 & 63.71646 & 72.77074 & 0.007763 & $6.85 \mathrm{E}-11$ & $7.27 \mathrm{E}-10$ \\
\hline $\mathbb{N}-103 A-G 2$ & IE-911 & 34283 & 198.5 & 199.0374 & 0.0527 & 0.91122 & 12985.32 & 11037.52 & 4.132938 & 234 & 56.61832 & 75.80414 & 0.007646 & $6.75 \mathrm{E}-11$ & $6.46 \mathrm{E}-10$ \\
\hline N-106A-GI & IE-911 & 34872 & 197 & 197.5333 & 0.054 & 0.91122 & \begin{tabular}{|l|}
13830.32 \\
\end{tabular} & 11755.78 & 4.445157 & 183 & 41.1684 & 77.5036 & 0.005921 & $8.94 \mathrm{E}-10$ & $4.7 \mathrm{E}-10$ \\
\hline N-106A-G2 & $|\mathbb{E}-9| 1$ & 31528 & 193.6 & 194.1241 & 0.0448 & 0.91122 & 18624.76 & 15831.05 & 4.91663 & 183 & 37.22062 & 79.66086 & 0.007209 & $1.09 \mathrm{E}-09$ & $4.25 \mathrm{E}-10$ \\
\hline N-75-11 & Sr Treat & 31083 & 192.8 & 193.322 & 0.0545 & 0.89664 & 14039.28 & 9967.887 & 4.548773 & 198 & \begin{tabular}{|l|l|}
43.52823 \\
\end{tabular} & 78.01605 & 0.006254 & $1.24 \mathrm{E}-10$ & $4.97 \mathrm{E}-10$ \\
\hline N-75-12 & Sr Treat & 31545 & 193.4 & 193.9236 & 0.0521 & 0.89664 & 14455.15 & 10263.16 & 4.482152 & 198 & 44.1752 & 77.68929 & 0.006535 & $1.29 \mathrm{E}-10$ & $5.04 \mathrm{E}-10$ \\
\hline$\overline{\mathrm{N}-103 \mathrm{~A}-\mathrm{II}}$ & Sr Treat & 33403 & 200.3 & 200.8423 & 0.0506 & 0.89664 & \begin{tabular}{|l|l|}
7318.383 \\
\end{tabular} & 5196.052 & 2.653212 & 234 & 88.19498 & 62.30984 & 0.006605 & $5.83 \mathrm{E}-11$ & T.01E-0! \\
\hline$\widehat{N-103 A-12}$ & Sr Treat & 51866 & 196.5 & 197.032 & 0.0509 & 0.89664 & 7476.667 & 5308,434 & 2.731838 & 234 & 85.65662 & 63.39461 & 0.006554 & $5.79 \mathrm{E}-11$ & $9.78 \mathrm{E}-10$ \\
\hline N-106A-II & Sr Treat & 41717 & 194.1 & 194.6255 & 0.0502 & 0.89664 & \begin{tabular}{|l|l|}
11742.85 \\
\end{tabular} & 8337.426 & 3.715787 & 183 & 49.24932 & 73.0878 & 0.005918 & $8.93 \mathrm{E}-10$ & $5.62 \mathrm{E}-10$ \\
\hline $\mathrm{N}-106 \mathrm{~A}-12$ & Sr Treat & 43689 & 197.4 & 197.9344 & 0.0517 & 0.89664 & \begin{tabular}{|l|}
10879.87 \\
\end{tabular} & 7724.704 & \begin{tabular}{|l|}
3.548067 \\
\end{tabular} & 183 & 51.57738 & 71.81564 & 0.005742 & $8.67 \mathrm{E}-10$ & $5.89 \mathrm{E}-1 \mathrm{C}$ \\
\hline N-75-J1 & SK-1(PSU) & 7888 & 198.8 & 199.3382 & 0.0481 & 0.94245 & 74422.87 & & 17.92463 & 198 & 11.04625 & 94.42109 & 0.008843 & $1.75 \mathrm{E}-10$ & $1.26 \mathrm{E}-10$ \\
\hline $\mathrm{N}-75-\sqrt{2}$ & SK-1(PSU) & 7540 & 201.5 & 202.0455 & 0.0516 & 0.94245 & \begin{tabular}{|l|l|}
73754.18 \\
\end{tabular} & & 18.75192 & 198 & 10.55892 & 94.66721 & 0.008376 & $1.66 \mathrm{E}-10$ & $1.21 \mathrm{E}-10$ \\
\hline $\mathrm{N}-103 \mathrm{~A}-\mathrm{N}$ & SK-1 (PSU) & 10756 & 201.6 & 202.1458 & 0.0523 & 0.94245 & 49923.46 & & \begin{tabular}{|l|l}
13.17300 \\
\end{tabular} & 234 & 17.76352 & 92.40875 & 0.009539 & $8.42 \mathrm{E}-11$ & $2.03 \mathrm{E}-1 \mathrm{C}$ \\
\hline $\mathbb{N}-103 A-J 2$ & SK-1 (PSU) & 10620 & 199.8 & 200.3409 & 0.051 & 0.94245 & 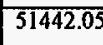 & & 13.34176 & 234 & 17.5389 & 92.50474 & 0.009705 & $8.57 \mathrm{E}-11$ & $2 \mathrm{E}-10$ \\
\hline N-106A-ग1 & SK-1 (PSU) & 7954 & 198.5 & 199.0374 & 0.0512 & 0.94245 & 76261.97 & & 19.4885 & 183 & 9.390155 & 94.86877 & 0.007703 & $1.16 \mathrm{E}-09$ & $1.07 \mathrm{E}-1 \mathrm{C}$ \\
\hline $\mathrm{N}-106 \mathrm{~A}-\mathrm{J} 2$ & SK-1 (PSU) & 8448 & 193.9 & 194.4249 & 0.051 & 0.94245 & 70177.1 & & 18.3489 & 183 & 9.97335 & 94.55008 & 0.007528 & $1.14 \mathrm{E}-09$ & $1.14 \mathrm{E}-1 \mathrm{C}$ \\
\hline & & & & & & & & & & & & & & & \\
\hline $\mid \mathrm{N}-1 / 2-\mathrm{X}]^{-1}$ & & 141389.5 & & & & & & & & & & & & & \\
\hline $\mathrm{N}-103 \mathrm{~A}-\mathrm{X} \mathrm{I}^{\mathrm{N}}$ & & 141689.5 & & & & & & & & & & & & & \\
\hline N-106A-XI' & & 155011.5 & & & & & & & & & & & & & \\
\hline
\end{tabular}




\section{Distribution}

No. of

Copies

OFFSITE

2 DOE/Office of Scientific and Technical Information

G. Allen

Department 6607/MS 0756

Sandia National Laboratories

P.O. Box 5800

Albuquerque, NM 87185-0756

D. H. Bandy

U.S. Department of Energy

P.O. Box 5400

Albuquerque, NM 87115

J. E. Baublitz, EM-40

DOE/Office of Environmental

Restoration

Forrestal Building

U.S. Department of Energy

1000 Independence Ave. SW

Washington, DC 20585 .

J. P. Bibler

Westinghouse Savannah River Co.

Building $773 \mathrm{~A}$

Aiken, SC 29802

2 W. W. Bixby, EM-60

DOE/Office of the Deputy Assistant

Secretary Facility

Transition and Management

U.S. Department of Energy

1000 Independence Ave. SW

Washington, DC 20585
No. of

Copies

N. E. Brown

6608 Loftus, NE

Albuquerque, NM 87109

R. L. Bruening 505 East 1860 South

IBC Advanced Technologies, Inc.

American Fork, UT 84603

J. Corones

Ames Laboratory

329 Wilhelm Hall

Iowa State University

Ames, IA 50011

R. Craig

HAZWRAP

P.O. Box 2003, MS 7606

Oak Ridge, TN 37831-7606

6 DOE/Office of Technology Development

Trevion II Building 12800 Middlebrook Road

Germantown, MD 20874

Attn: G. G. Boyd

EM-50

S. T. Lien EM-53

R. T. Parker EM-52

P. J. Ritzcovan EM-542

W. C. Schutte EM-54

S. M. Wolfe ' EM-532

Distr.1 
No. of

\section{Copies}

5 DOE/Office of Waste Management Trevion II Building 12800 Middlebrook Road Germantown, MD 20874

Attn: J. O. Boda

J. A. Coleman

S. P. Cowan

S. L. Domotor

H. F. Walter

N. Egan

Program Development Division

MSE Inc.

P.O. Box 3767

Butte, MT 59702

D. Emillia

Strategic Planning Dept.

Chem-Nuclear Geotech

P.O. Box 1400

2597B-3/4 Road (81503)

Grand Junction, CO 81502-2567

B. Erdal

Los Alamos National Laboratory

MS D446

Los Alamos, NM 87545

D. J. Fennelly

UOP Corp.

307 Fellowship Road

Suite 207

Mt. Laurel, NJ 08054

2 J. J. Fiore, EM-42

DOE/Office of Environmental

Restoration

Trevion II Building

12800 Middlebrook Road

Germantown, MD 20874
No. of

Copies

EM-32

EM-35

EM-30

EM-35

EM-34
C. W. Frank, EM-50

DOE/Office of Technology Department

Forrestal Building

U.S. Department of Energy

1000 Independence Ave. SW

Washington, DC 20585

E. Franz

Brookhaven National Laboratory

Building 830

Upton, NY 11973

K. D. Gerdes, EM-532

DOE/Office of Technology Development 19901 Germantown Road

Germantown, MD 20874

J. E. Helt

Office of Waste Management Programs 9700 South Cass Avenue

Argonne, IL 60439-4837

R. Jacobson

Desert Research Institute

P.O. Box 19040

Las Vegas, NV 89132

3 T. M. Kafka

3M Center

Bldg. 209-1W-24

St. Paul, MN 55144-1000

K. Kibbe

Martin Marietta Energy Systems

P.O. Box 2003

Bldg. K-1011, MS 7172

Highway 58

Oak Ridge, TN 37831-7172 
No. of

Copies

Dr. Sridhar Komarneni

Professor of Clay Mineralogy

205 Materials Research Laboratory

The Pennsylvania State University

University Park, PA 16802

K. Kostelnik

EG\&G Idaho, Inc., MS 3930

P.O. Box 1625

200 South Woodruff

Idaho Falls, ID 83415-3970

J. E. Lytle, EM-30

DOE/Office of Waste Operations

Forrestal Building

U.S. Department of Energy

1000 Independence Ave. SW

Washington, DC 20585

\section{J. F. McGlynn}

SAIC

555 Quince Orchard Road, Suite 500

Gaithersburg, MD 20878

Frances Fadullon

SAIC

555 Quince Orchard Road, Suite 500

Gaithersburg, MD 20878

K. McWilliam

U.S. Department of Energy

Nevada Operations Office

P.O. Box 98518

Las Vegas, NV 89109

J. Moore

U.S. Department of Energy

Oak Ridge Operations Office

P.O. Box E

Oak Ridge, TN 37831
No. of

Copies

K. Nuhfer

FERMCO

P.O. Box 398704

Cincinnati, OH 45239-8704

9 Oak Ridge National Laboratory

P.O. Box 2008

Oak Ridge, TN 37831-6223

Attn: J. B. Berry

MS-6044

J. L. Collins

MS-6221

B. Z. Egan

MS-6223

R. D. Hunt

D. Lee

MS-6273

A. P. Malinauskas

C. P. McGinnis

J. F. Walker

J. S. Watson

MS-6221

MS-7271

MS-6273

MS-6149

MS-6149
D. Olona

U.S. Department of Energy

Albuquerque Operations Office

P.O. Box 5400

Albuquerque, NM 87115

B. Park

MSE Inc.

P.O. Box 4078

Butte, MT 59702

P. J. Pettit

P.O. Box 538704

MS 81-2

Cincinnati, $\mathrm{OH}$ 45253-8704

R. W. Rice

MSE, Inc.

307 Quincy

El Paso, TX 79922 
No. of

\section{Copies}

2 Sandia National Laboratories

P.O. Box 5800

Albuquerque, NM 87185-5800

Attn: J. E. Miller

MS-0709

J. Nelson

MS-6621

R. Smith

Environmental Consultant

645 N. Ewing Street, \#6

Helena, MT 59601

G. Staats

U.S. Department of Energy

Pittsburgh Energy Technology Center

P.O. Box 10940

Pittsburgh, PA 15236-0940

J. L. Steele

Savannah River Site

SRL, 773 A, A208

Aiken, SC 29802

S. L. Stein

Battelle Seattle Research Center

$4000 \mathrm{NE} 41^{\text {st }}$ Street

Seattle, WA 98105

K. Stevenson

U.S. Department of Energy

376 Hudson Street

New York, NY 10014-3621

J. L. Swanson

1318 Cottonwood Drive

Richland, WA 99352

J. Sweeney

U.S. Department of Energy

Oak Ridge Operations Office

P.O. Box E

Oak Ridge, TN 37831
No. of

\section{Copies}

I. R. Tasker

Waste Policy Institute

Quince Diamond Executive Center

555 Quince Orchard Road

Gaithersburg, MD 20878-1437

M. C. Thompson

Savannah River Technology Center

P.O. Box 616

Aiken, SC 29802

T. A. Todd

Lockheed Idaho Technology Company

P.O. Box 1625, MS 5213

Idaho Falls, ID 83415

J. Tourikis

MSE Inc.

P.O. Box 4078

Butte, MT 59702

C. Tsang

Earth Sciences Division

Bldg. 50E

Lawrence Berkeley Laboratory

Berkeley, CA 94720

UOP Corp.

50 East Algonquin

Des Plains, IL 60017-5016

Attn: J. Sherman

R. Braun

S. Webster

U.S. Department of Energy

Chicago Field Office

9800 South Cass Avenue

Argonne, IL 60439-4837

Distr.4 
No. of

Copies

T. Williams

U.S. Department of Energy

Idaho Operations Office

785 DOE Place

Idaho Falls, ID 83402

J. Wright

U.S. Department of Energy

Savannah River Operations Office

RFD \#1, Bldg. 703A, Rm. E208 North

P.O. Box A

Aiken, SC 29802

S. Yates

AlliedSignal

50 East Algonquin Road

Des Plaines, IL 60017-5016

J. Yow

Lawrence Livermore National Laboratory

7000 East Avenue

P.O. Box 808

Livermore, CA 94550

C. Zeh

Morgantown Energy Technology Center

3610 Collins Ferry Road

Morgantown, WV 26507-0880
No. of

\section{Copies}

7 Bechtel Hanford, Incorporated

A. G. Duda

H0-18

M. H. Hyman

$\mathrm{H} 4-80$

S. A. Hobart

H4-80

K. J. Koegler

$\mathrm{H} 0-18$

S. Kretzschmar

X5-54

M. J. Lauterbach

X5-54

S. K. Pulsford

X5-53

2 CH2M Hill Hanford, Inc.

T. E. Moody

H9-03

D. J. Vaught

H9-01

2 Flour Daniel Hanford, Inc.

G. T. Berlin

H6-34

D. J. Washenfelder

H5-27

4 Lockheed Martin Hanford Corp.

J. N. Appel

G3-21

S. A. Barker

R2-11

W. B. Barton

R2-11

K. A. Gasper

G3-21

\section{MACTEC}

D. J. Swanberg

K8-50

2 Numatec Hanford Corporation

K8-50

K8-50

S7-53

S7-53

K8-50

K8-50

D. E. Trader

S7-53
D. L. Herting

R. A. Kirkbride
T6-09

H5-27 
No. of

Copies

4 SGNeurisys Services Corporation

M. D. Britton

H5-49

K. M. Eager

H5-27

M. J. Klem

D. L. Penwell

H5-27

H5-27

53 Pacific Northwest National Laboratory

J. E. Amonette

K9-77

W. F. Bonner

L. A. Bray

K. P. Brooks

T. M. Brouns

S. A. Bryan

K. J. Carson
No. of

Copies

C. D. Carlson (20) P7-25

R. J. Elovich P7-25

J. A. Franz K2-44

J. M. Gephart K2-21

L. K. Holton K9-73

T. L. Hubler P8-38

W. L. Kuhn K2-21

D. E. Kurath P7-20

J. P. LaFemina K2-25

M. E. Peterson K2-47

R. K. Quinn K9-69

W. G. Richmond K9-33

L. J. Sealock K2-10

J. T. Slankas $\quad$ K9-81

S. O. Slate P8-44

Technical Report Files (5)

PNNL Information Release

Office (7)

$\mathrm{K} 1-11$ 